\title{
The Impact of Marketing Mix on Perceived Value, Destination Image and Loyalty of Tourists (Case Study: Khalkhal City, Iran)
}

\author{
Saeideh Esmaili ${ }^{1}$, Nafiseh Rezaei ${ }^{1}$, Reza Abbasi ${ }^{1} \&$ Samane Eskandari ${ }^{1}$ \\ ${ }^{1}$ Department of Business Management, Faculty of Management, University of Tehran, Tehran, Iran \\ Correspondence: Nafiseh Rezaei, Department of Business Management, Faculty of Management, University of \\ Tehran, Tehran, Iran. E-mail: nafis.h.rezaei@gmail.com
}

Received: October 1, 2017

Accepted: October 18, 2017 Online Published: October 31, 2017

doi:10.5539/mas.v11n11p96

URL: https://doi.org/10.5539/mas.v11n11p96

\begin{abstract}
This study examines the relationship between marketing mix with loyalty, perceived value, perceived quality and destination image. This is an applied descriptive study the aim of which is to determine the impact of marketing mix of services (Product, Pricing, Place, Promotion, People, Process and Physical Evidence) on perceived quality, loyalty, perceived value and destination image of the tourists in Khalkhal city, Iran. Population of the study included all the tourists visiting Khalkhal city from among whom 385 respondents participated in this study. A questionnaire was used for data collection. The conceptual model was analyzed based on linear regression analysis in SPSS software and model fitness was analyzed using LISERL software. Cronbach's alpha of the questionnaire was equal to 0.791 that is higher than 0.7 and so reliability of the questionnaire was acceptable. Findings of the study showed that promotion, people and physical evidences had the highest effect on perceived value, destination image and perceived quality. Finally, some suggestions were provided for the managers of the tourism destinations to improve the perceived value and quality and also develop a proper destination image.
\end{abstract}

Keywords: marketing mix, perceived value, destination image, perceived quality, tourism destination image, Khalkhal City, Iran

\section{Introduction}

The rapid development of tourism industry has made many experts and scholars to call the $20^{\text {th }}$ century, "The Century of Tourism". Tourism industry can be considered not only as one of the most important phenomena of the century throughout the world, but also as one of the most profitable industries in various countries (Hassannejad et al., 2014, p. 90). Since the second half of the $20^{\text {th }}$ century, the number of international tourists has been incredibly increasing. Many countries have become the new tourism destination and markets for trip demand. At the beginning of the third millennium, tourism industry has become one of three main businesses of the world beside automobile and oil industry (Ilkhani et al., 2016, p. 322). Therefore, we are witnessing that many countries perceive the prior position of tourism industry in various economic development models and so have been looking for developing their tourism facilities during the last years. These countries, in a close competition, are trying to increase their benefits and revenues from this international activity more than before. Gaining success in this domain and access to material and immaterial revenues requires understanding tourism phenomenon, identification of its aspects and consequences (Kazemi, 2011).

Tourists and their behaviors should be studied to be successful in tourism domain. Examination of tourists' behaviors is more difficult than studying the behaviors of other commodity and service customers. This may be due to the fact that at the end of a trip, there is nothing tangible and visible left (Kazemi, 2008, p. 83). This is due to the service nature of this industry. One of the common mistakes in tourism is that marketers consider tourists satisfaction as the end product of their business. It should be taken into account that satisfaction does not always predict and explain loyalty, perceived quality, and development of positive destination image. These factors are highly significant in marketing studies.

Many studies stated various advantages of purchase frequency including that attraction of a new customer has a higher cost than maintaining the current customers and purchase frequency and previous studies have proven that $5 \%$ of purchase frequency leads to an equivalent of 25 to $85 \%$ and most importantly, it provides a proper brand or destination image which in turn results in word of mouth (WOM) and positive view of products and service (Reichheld \& Sasser, 1990). 
Repeated visits to a tourism destination have many significant effects and advantages at macro and micro economic level (Darnell \& Johnson, 2001, p. 119-126). In fact, many tourism attractions seriously rely on tourists' visits (Gitelson \& Crompton, 1984). In recent years, there have been many studies on identifying the effective factors on visitors and loyalty of the tourists to that destination. These studies have found predictors such as satisfaction, service quality (Baker \& Crompton, 2000; Kozak \& Rimmington, 2000; Petrick et al., 2001; Yuksel,), perceived value (Petrick et al., 2001), previous experiences (Chen \& Gursoy, 2001; Kozak, 2001; Petrick et al., 2001), safety (Chen \& Gursoy, 2001), destination image (Milman \& Pizam, 1995; Ross, 1993). Given the economic importance and benefits of loyalty, perceived value and destination image of tourist attractions, this study examines the effects of marketing mix elements on perceived value, perceived quality and destination image of tourism attractions and their impact on destination loyalty to tourism attraction sites of Khalkhal.

\section{Area Descriptions}

\subsection{Service Marketing Mix}

Given the increasing rate of using services and employment at service sector all over the world, as the social and business activities get more complicated, specialized and competitive, the services sector grows more and managers need to become familiar with the service marketing principles in order to better manage their organizations in today's highly active and competitive world, and to take advantage of marketing techniques to deliver services and satisfy customers' needs (Pamela \& Robert, 1999).

Precise identification of present condition through tourism marketing is one of the main aspects which can be the sources of sustainable development for tourism. It is also one of the concepts to be used to explain the present condition and plan to achieve proper condition for tourism industry of a region (Ghadiri et al., 2013). Botten and McManus (1999) classified service marketing variables as seven strategic factors (7Ps) as following: 1- product (service), 2- price, 3- place (with distribution), 4- promotion, 5- physical evidence (e.g., building, uniforms, etc.), 6- people (employees and customers) and 7- process (procedure, etc.).

\subsection{Tourism Destination Image}

Marketing the destination image is the beginning of a successful tourism marketing since image and expectation of trip experiences of visitors in future is tightly related to their thoughts to the specific destination (Levitt, 1986, cited in Chao, 2005, p. 1). Destination image is one of the most importantly discussed issue in marketing research at tourism industry so that many countries use promotional and global marketing tools to support their image and compete with other destinations. This concept is very important in tourism, because it affects the behavior and decision of tourists and plays an important role in their satisfaction with trip (Beerlie \& Martin, 2004, p. 660). Furthermore, destination image is one of the interesting issues for tourism marketers since it is an essential element of destination positioning, creation and management of a distinctive and appealing perception, or image, of the destination (Ritchie \& Echtner, 1993, p. 37).

Without a successful destination image marketing, a place cannot be able to attract tourists and maintain its tourism advantage. In order to be successful in the target market, the destination must distinguish itself in the proper and appropriate manner from its rivals and position itself in customers' mind. The key element of the process is to capture, manage, and create an attractive and distinctive image of the destination (ibid, p. 38). Mental image of destination includes a mental schema or personal and group perception of a destination. In addition, mental image can indicate a simplified set of perceptions which includes many information about a place. In sum, mental image of destination is a personal perception of a place which can change from person to person (Chao, 2005; 5).

\subsection{Perceived Quality of Tourism Destination}

Perceived quality is the general judgement of the consumer about the priority of the product or service which is obtained by a combination of expectations and perceptions of the consumers. Perceived quality is an effective element in general promotion of satisfaction. If the consumers' perception of services and products are desired, consumers' satisfaction is increased and if it is evaluated as improper, it would reduce the consumers' satisfaction.

Simply put, quality means meeting the expectation or exceeding expectations (Gholizadeh Sarvari, 2012). According to Brady and Cronin (2001) customers' perception of service quality is formed based on their evaluation of three main aspects of quality that is interaction quality, service quality and outcome quality. Quality evaluation is a difficult task since most tourism destinations do not have quality control centers (Gholizadeh Sarvari, 2012). Many studies on tourism have shown that perceived quality control is the most 
effective factor on satisfaction and loyalty. Perceived quality also affects perceived value. Murphy et al. reported that perceived quality of trip has a positive effect on perceived value of trip. Chen and Tasi (2007) found that destination image has a positive effect on "behavioral intentions through trip quality and satisfaction, which in turn affects behavioral intentions" (Cited in Lin, 2011, p. 41).

\subsection{Loyalty to Tourism Destination}

Loyalty is so widely accepted as the main marketing tool, the importance of which is quite clear for everyone in business domain. The loyalty ratio is one of the measurement indices of marketing strategy achievement. Brand loyalty plays a prominent role in the development of brand equity, not only because of the ability to maintain a loyal customer base, but also due to the expansion of customer loyalty to other brands of the same company. On the other hand, some researchers define brand loyalty as a customer affiliation with the brand. Dick and Basu (1994) believed that brand loyalty leads to many marketing advantages such as reduction in marketing prices, more new customers and more commercial penetration (cited in Huh, 2006). They have also pointed to other benefits of brand loyalty as higher resistance of loyal customers to rivals strategies. Moreover, brand loyal customers have an image about the unique value of brand which no other brand can have such specification and so they have to pay more for this brand (Huh, 2006). Most studies in the field of tourism have considered repeated visits and attitude to return as loyalty indices (Nam et al., 2011).

Tourism studies indicated the role of trip satisfaction in loyalty to destination. Tourists' loyalty to destination reflects in their intentions to revisit the destination and to suggest it to others. Positive experience of tourists about services, products and other provided resources in tourism destination leads to repeated visits and also have positive effect of word of mouth marketing to friends and other relatives (Konecnik \& De Chernatony, 2010). In sum, many researchers and scholars believe that loyalty includes two behavioral and attitudinal components. Though, some others also add a combinational approach to these two components. Positive attitudinal loyalty helps the customers to be obliged to the brand and prefer that brand over other brands. Here, commitment and psychological loyalty are emphasized. Behavioral loyalty indicates that knowing previous experiences affects the common and future decisions of tourists, more specifically in selecting tourism destination.

\subsection{Perceived Value of Tourism Destination}

Zeithaml (1998) defined perceived value as: "perceived value is the consumer's overall assessment of the utility of a product based on perceptions of what is received and what is given (p. 14). Jung Sun (2013) believe that perceived value is a comprehensive evaluation of costs and tangible and intangible benefits. Baldauf et al. (2003) found that "loyal customers recognize a favorable benefit opportunity, and customers who are familiar with products and logos willingly pay a price premium. In other words, brand loyalty and brand awareness are positively related to perceived value" (cited in Ghloizadeh Sarvari, 2012, p. 31). According to Kim et al (2009) perceived quality has significant effect on perceived value (cited in Ghloizadeh Sarvari, 2012). Studies have shown that perceived value is one of the most important and effective factors on loyalty (e.g. Baker \& Crompton, 2000; Yoon et al, 2010).

\subsection{Research Background}

Huang and Sarigöllü (2012) examined the relationship between brand awareness with brand equity and marketing mix. Results of the study showed that experience of consumers about brand usage results in brand awareness. Also, findings indicated a positive relationship between brand awareness and brand equity. Beristain and Zorrilla (2011) examined the ways for increasing the official quality, loyalty and brand awareness by using store image and price as the variables. It was found that store image is an important factor for retailers for increasing the perceived quality, awareness and store loyalty. A positive and significant relationship was found between store image with quality, loyalty and brand awareness.

Further, findings indicated a positive relationship between price with loyalty, awareness and negative relationship with quality. Kim and Hyum (2010) in their study, entitled as "A model to investigate the influence of marketing-mix efforts and corporate image on brand equity in the IT software sector" examined the relationship between marketing mix including distribution, price and corporate image on three aspects of brand awareness, perceived quality and brand loyalty. Results of the study indicated a positive relationship between marketing mix performance and brand equity and corporate image modified the effect of marketing mix on three aspects of brand equity.

Tong and Hawley (2009) in a study, entitled as "Creating brand equity in the Chinese clothing markets the effect of selected marketing activities on brand equity dimensions" showed that store image and various promotion 
methods and sale promotion such as discount strategy and cost reduction had positive effect on brand equity in China.

Ghadiri et al. (2013) evaluated and prioritized the effective indices in rural tourism marketing with marketing mix P7 model. Results of the study showed that seven components of marketing mix (Place, Price, Product, Promotion, People, Process, Physical Evidence and also Political and social situation) has the potential to clearly indicate the current condition of rural marketing in the region and secondly improve the rural development through development of rural tourism and reaching Mazandaran Province to a proper developmental status.

Anari Dehghani et al. (2014) examined the factors affecting tourists' loyalty to tourism destination and concluded that mental image of destination can significantly and positively affect the perceived value and satisfaction of destination in tourism. Finally, results of the study showed that tourists' satisfaction about destination can have positive and significant effect on loyalty but perceived value of tourism destination cannot affect destination loyalty.

In addition, Soleimani and Mansouri Moaied (2012) examined the marketing tools and destination image of tourists. It was found that internet, which is the most important tool for getting information on destination, significantly affects the emotional image of the tourists. Meanwhile, various marketing tools including word of mouth, brochures and journals were at the second and third place following internet.

Hemati and Zahrani (2014) examined the factor affecting satisfaction and loyalty of foreign tourists to Isfahan as tourism brand. Results of the study showed that awareness and acquaintance of tourists with Isfahan and image of Isfahan as a tourist destination in mind of the foreign tourists directly affected tourists' satisfaction through perceived value and perceived quality.

Zangane and Shamsollahzadeh (2012) examined and analyzed the role of destination image in development of tourism industry in Tabriz city, Iran. Results of the study showed that traveling to Tabriz made a positive change in mind of tourists and also there was a positive correlation between perceived face of tourism after trip and their tendency to return. The important point regarding obtaining information about destination by tourists showed the main role of traditional methods (family and friends) in obtaining information before traveling to this city.

Imani Khoshko and Ayoubizadeh $(2010$, b) conducted a study about effective factors on brand equity in tourism destination of Yazd. Results of the study showed that in addition to brand image, brand loyalty, perceived value and brand awareness about tourism destination also directly affect the brand equity of Yazd. And brand loyalty is the most effective factor in terms of importance. They also conduced another study $(2010$, a) to examine the tourists' destination of Kish and Gheshm based on a conceptual model. Results of the study showed that tourists have more awareness about Kish compared to Gheshm. However, other variables such as brand image, perceived quality and brand loyalty are same for these two islands.

Iranzadeh et al. (2012) examined the effect of marketing mix on brand equity. Results of structural equation analysis indicated effect of price and product variables on loyalty, perceived quality, brand awareness and brand association. Regarding the relationship between marketing mix with brand equity dimensions, two elements of price and product are related to three dimensions of brand equity. And given the correlation coefficients of these relationships are positive, therefore, it should be cautious about pricing policies. Also, in the case of a product, the company should be careful about changing the functional and apparent features.

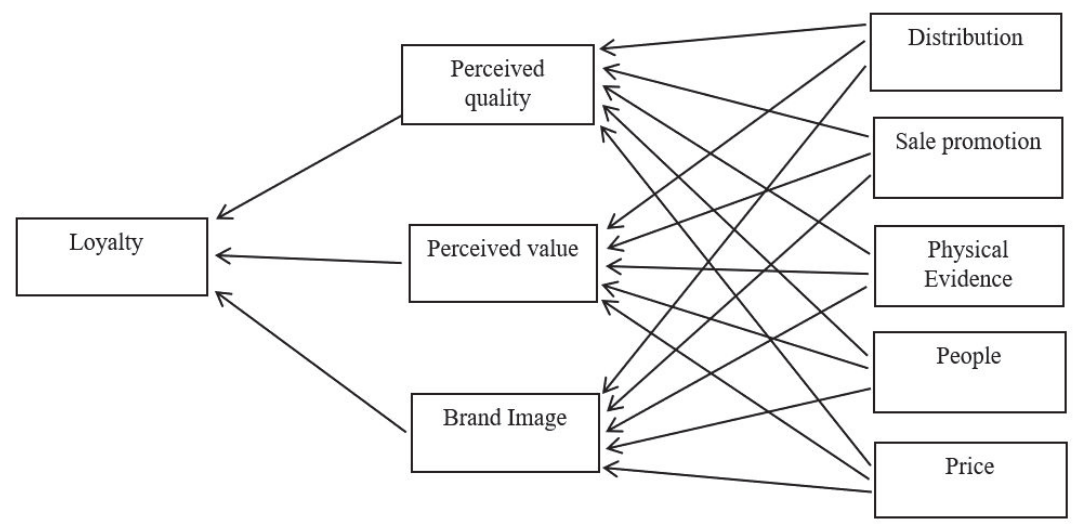

Figure 1. Conceptual Model

Given the research model, following hypotheses are suggested: 
H1: Price influences the perceived quality of Khalkhal as a tourism destination

$\mathrm{H} 2$ : Price influences the image of Khalkhal as a tourism destination

H3: Physical evidence influences the perceived quality of Khalkhal as a tourism destination

H4: Distribution influences the perceived quality of Khalkhal as a tourism destination

H5: People influences the perceived quality of Khalkhal as a tourism destination

H6: Sale promotion influences the perceived quality of Khalkhal as a tourism destination

H7: Distribution influences the image of Khalkhal as a tourism destination

H8: Sale promotion influences the image of Khalkhal as a tourism destination

H9: People influences the perceived value of Khalkhal as a tourism destination

H10: Distribution influences the perceived value of Khalkhal as a tourism destination

H11: Sale promotion influences the perceived value of Khalkhal as a tourism destination

H12: Physical evidence influences the perceived value of Khalkhal as a tourism destination

H13: Perceived quality influences the loyalty of Khalkhal as a tourism destination

H14: Destination image influences the loyalty of Khalkhal as a tourism destination

H15: Perceived value influences the loyalty of Khalkhal as a tourism destination

H16: price influences the loyalty of Khalkhal as a tourism destination

H17: Physical evidence influences the loyalty of Khalkhal as a tourism destination

H18: Distribution influences the loyalty of Khalkhal as a tourism destination

H19: People influences the loyalty of Khalkhal as a tourism destination

H20: Sale promotion influences the loyalty of Khalkhal as a tourism destination

\section{Method}

\subsection{Data Collection}

This is an applied study in terms of purpose and a descriptive survey in terms of methodology. Population of the study included all the visitors of Khalkhal city, Iran. Participants of the study were selected based on random sampling. Given that population of the study is unlimited, Cochran formula was used to calculated sample size as below:

$$
\begin{gathered}
n=\frac{\sigma^{2} z_{1-\alpha / 2}^{2}}{\varepsilon^{2}}=\frac{\left(\frac{1}{2}\right)\left(\frac{1}{2}\right)(1.96)^{2}}{(.05)^{2}} \cong 385 \\
\varepsilon=0.05 \alpha=0.05 \rightarrow z_{1-\alpha} / 2=z_{.975}=1.96 \mathrm{p}=\mathrm{q}=0.5
\end{gathered}
$$

The research questionnaire included 29 items and developed based on the variables included in the model developed by Yoo, Danto and Lee (2000). The questionnaire is based on a 5-point Likert scale. The number of items and variables constructs of the questionnaire are as follows: paid money to measure the price; cost of the services provided in the destination according to travelers' demand and in comparison with other destinations, constructs such as the optimal quality of attractions and the new features of services to measure the product variability; construct such as the diversity of services, passengers need and the ease of access and speed of the service to measure the distribution variable; constructs such as the staff treating tourists with courtesy and respect and skill and knowledge of employees about the work to measure the variable of people; creative designs for attracting tourists; discounts, incentives, advertising and information to measure the variable of promotion as a new construct; better and more reliable service constructs and optimal atmospheres governing destination, the utility of the services provided at the destination to measure the variable quality from the viewpoint of travelers; good visit of the destination, the reasonable price, the money paid to measure the value of the organization construct; constructs such as the weather of the city, the availability of travel information, the adventure atmosphere of the city, the hospitality rate of the residents and the natural attractions and beautiful landscapes of the city to measure image; and the return, trust, the proposal of this trip to others and the destination priority to measure the loyalty variable.

Each construct is presented by one or more separate items in the questionnaire. The validity of the questionnaire 
was verified by face validity, and for examining reliability, the questionnaire was first distributed among 30 tourists and after collection, the Cronbach's alpha value of 0.791 was obtained which is higher than 0.7 . Thus, the reliability is confirmed. The alpha Cronbach coefficient of is given separately in the table 1. Product, Pricing, Place, Promotion, People, Process and Physical Evidence.

Table 1. Cronbach's alpha of variables

\begin{tabular}{lc}
\hline Variables & Cronbach's alpha \\
\hline Pricing & 0.823 \\
Product & 0.890 \\
Place & 0.709 \\
People & 0.752 \\
Promotion & 0.796 \\
Perceived quality & 0.710 \\
Perceived value & 0.826 \\
Destination image & 0.782 \\
Destination loyalty & 0.825 \\
\hline
\end{tabular}

\subsection{Study Area}

Khalkhal city with an area of 2,800 square kilometers in the north of Iran's plateau between 48 degrees and 32 minutes longitude and 37 minutes and 37 degrees latitude from the Greenwich Meridian and with elevations more than 1500 meters above sea level is located in northwest Iran and south of the province Ardebil which ends from north to Kosar city, east to Gilan province, west to East Azarbaijan province and city of Mianeh, and south to Zanjan province (figure 2) and its distance is $114 \mathrm{~km}$ from the center of the province (Alizadeh, 2012, p.81). The city of Khalkhal, due to its particular climates and attractions, ecotourism capabilities and historical and religious memories, can attract tourists at a higher scale. The special rituals and traditions of the inhabitants of this city, the diversity of languages and religions and the rich culture of the city are among other tourist attractions. Further, the ancient hills dating back to several thousand years old and highly recorded works are among this city's tourism potential (Aghaei Hashjin, 2009).

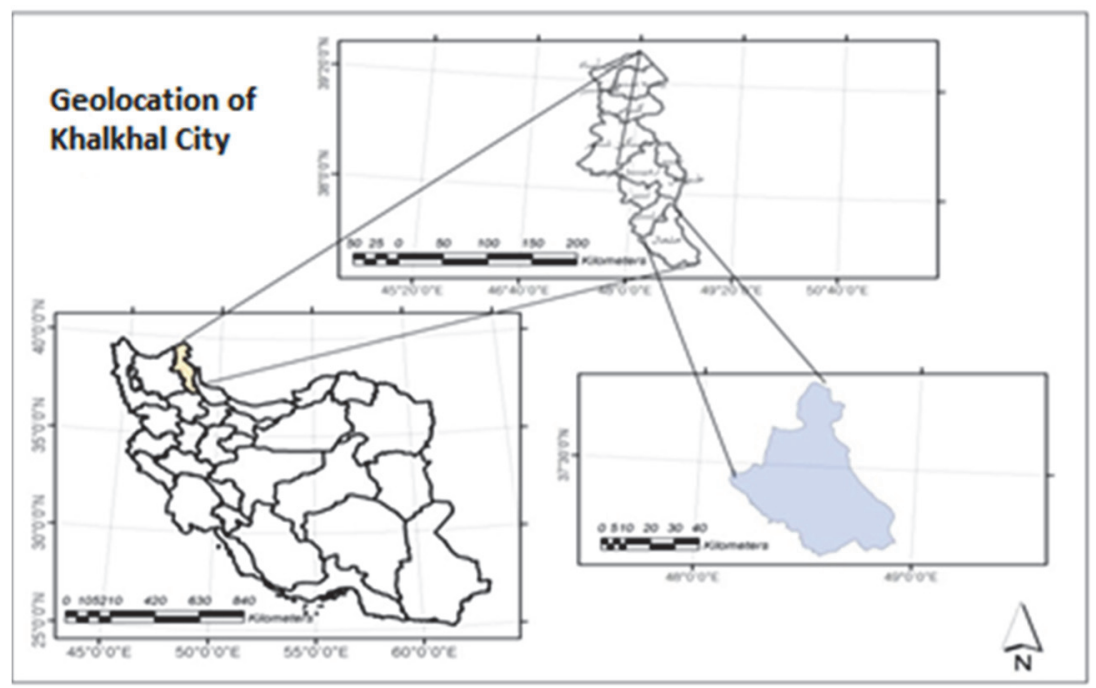

Figure 2. Geolocation of Khalkhal city

\section{Results}

Following collection of data using SPSS software, data analysis was conducted at descriptive and inferential level. Regarding descriptive analysis, the collected data were analyzed in terms of gender, age, marital status and 
education. Results of the analysis are as the following:

Table 2. Descriptive Statistics

\begin{tabular}{|c|c|c|c|c|}
\hline Index & \multicolumn{4}{|c|}{ Frequency } \\
\hline \multirow[t]{2}{*}{ Gender } & \multicolumn{2}{|c|}{ female } & \multicolumn{2}{|r|}{ male } \\
\hline & \multicolumn{2}{|c|}{$33 / 6$} & \multicolumn{2}{|r|}{$66 / 4$} \\
\hline \multirow[t]{2}{*}{ Age } & $18-25$ & $26-35$ & $36-45$ & 45 and older \\
\hline & 30.5 & 43.5 & 17.9 & 7.8 \\
\hline \multirow[t]{2}{*}{ Education } & $\begin{array}{l}\text { Less than high } \\
\text { school } \\
\text { diploma }\end{array}$ & $\begin{array}{l}\text { High school } \\
\text { diploma and } \\
\text { college degree }\end{array}$ & $\begin{array}{l}\text { Bachelor's } \\
\text { degree }\end{array}$ & $\begin{array}{l}\text { Master's degree and } \\
\text { higher }\end{array}$ \\
\hline & 14.7 & 29.9 & 45.8 & 9.6 \\
\hline Marital & \multicolumn{2}{|c|}{ Single } & Married & Others \\
\hline Status & \multicolumn{2}{|c|}{45.9} & 48.1 & 5.9 \\
\hline
\end{tabular}

The Pearson correlation test, regression analysis (Table 3), Mann-Whitney and Kruskal-Wallis H test (Table 4) and path analysis technique (Table 5) were used for inferential statistics. For example, given hypothesis 1, the statistical hypotheses are as follows:

H0: Distribution does not affect the perceived quality of Khalkhal as a tourism destination

H1: Distribution affects the perceived quality of Khalkhal as a tourism destination

First, Pearson correlation coefficient was used to test the existence or absence of a relationship between the two variables of distribution and the perceived quality of Khalkhal tourism destination. The hypothesis and null hypothesis are as follows:

H0: $\mathrm{P}=0$ If sig. (2-tailed) $>\alpha=0.05 \longrightarrow \mathrm{H} 0$

$\mathrm{H} 0: \mathrm{P} \neq 0$ If sig. (2-tailed) $>\alpha=0.05 \longrightarrow \mathrm{H} 1$

Since the significance level of 0.775 is higher than 0.05 , the null hypothesis is not rejected, and it can be said that there is not a significant relationship between the distribution and the perceived quality of the destination. Therefore, the distribution of perceived quality does not affect the tourism destination of Khalkhal.

Given the second hypothesis, the statistical assumptions are as the following:

H0: Sale promotion does not affect the perceived quality of Khalkhal as a tourism destination

H1: Sale promotion affects the perceived quality of Khalkhal as a tourism destination

First, Pearson correlation coefficient was used to test the existence or absence of a relationship between the two variables of sale promotion and the perceived quality of Khalkhal tourism destination. The hypothesis and null hypothesis are as follows:

H0: $\mathrm{P}=0$ If sig. (2-tailed) $>\alpha=0.05 \longrightarrow \mathrm{H} 0$

H0: $\mathrm{P} \neq 0$ If sig. (2-tailed) $>\alpha=0.05 \rightarrow \mathrm{H} 1$

Since the significance level of 0.000 , it can be stated with 0.99 percent confidence that the null hypothesis is rejected, and it can be said that there is a significant relationship between the sale promotion and the perceived quality of the destination with a significance of -0.110 reverse and negative relationship between sale promotion and destination image. Now, through regression analysis, we examine the effect of the sales promotion variable on the destination image variable, assuming that other marketing mix elements are constant. The regression model consists of four outputs, the first output is the independent variable included into the model, which is the sales promotion variable. In the second output, the correlation coefficient between the two variables of sales promotion and the destination image or $\mathrm{R}$ is 0.110 .

By inclusion of the variable sale promotion in the model, the coefficient of determination (R2) is 0.012 . That is, 0.012 changes the destination image of Khalkhal tourism are related to the sale. The beta value is equal to 0.110 , that is, assuming no other variables per unit increase in the standard deviation reduces the sales promotion as 0.110 units of standard deviation of the destination image. According to the explanation, the null hypothesis is rejected and the hypothesis is confirmed. Therefore, it can be said that sales promotion affects the image of the 
Khalkhal tourism destination. Other hypotheses have also been tested in the same way and the results are summarized in the following table:

Table 3. Results of Research Hypothesis Analysis

\begin{tabular}{|c|c|c|c|c|}
\hline Raw & Research Hypothesis & Coefficient & sig & Results \\
\hline The first hypothesis & $\begin{array}{l}\text { H1: Price influences the perceived quality of Khalkhal } \\
\text { as a tourism destination }\end{array}$ & 0.029 & 0.775 & Rejected \\
\hline $\begin{array}{l}\text { The second } \\
\text { hypothesis }\end{array}$ & $\begin{array}{l}\text { H2: Price influences the image of Khalkhal as a } \\
\text { tourism destination }\end{array}$ & -0.110 & 0.000 & Approved \\
\hline $\begin{array}{l}\text { The third } \\
\text { hypothesis }\end{array}$ & $\begin{array}{l}\text { H3: Physical evidence influences the perceived quality } \\
\text { of Khalkhal as a tourism destination }\end{array}$ & 0.235 & 0.019 & Approved \\
\hline $\begin{array}{l}\text { The fourth } \\
\text { hypothesis }\end{array}$ & $\begin{array}{l}\text { H4: Distribution influences the perceived quality of } \\
\text { Khalkhal as a tourism destination }\end{array}$ & 0.324 & 0.001 & Approved \\
\hline The fifth hypothesis & $\begin{array}{l}\text { H5: People influences the perceived quality of } \\
\text { Khalkhal as a tourism destination }\end{array}$ & 0.000 & 0.998 & Approved \\
\hline $\begin{array}{l}\text { The sixth } \\
\text { hypothesis }\end{array}$ & $\begin{array}{l}\text { H6: Sale promotion influences the perceived quality of } \\
\text { Khalkhal as a tourism destination }\end{array}$ & 0.515 & 0.000 & Approved \\
\hline $\begin{array}{l}\text { The seventh } \\
\text { hypothesis }\end{array}$ & $\begin{array}{l}\text { H7: Distribution influences the image of Khalkhal as a } \\
\text { tourism destination }\end{array}$ & 0.143 & 0.000 & Approved \\
\hline $\begin{array}{l}\text { The eighth } \\
\text { hypothesis }\end{array}$ & $\begin{array}{l}\text { H8: Sale promotion influences the image of Khalkhal } \\
\text { as a tourism destination }\end{array}$ & -0.118 & 0.241 & Approved \\
\hline $\begin{array}{l}\text { The ninth } \\
\text { hypothesis }\end{array}$ & $\begin{array}{l}\text { H9: People influences the perceived value of Khalkhal } \\
\text { as a tourism destination }\end{array}$ & -0.025 & 0.785 & Approved \\
\hline $\begin{array}{l}\text { The tenth } \\
\text { Hypothesis }\end{array}$ & $\begin{array}{l}\text { H10: Distribution influences the perceived value of } \\
\text { Khalkhal as a tourism destination }\end{array}$ & 0.387 & 0.000 & Approved \\
\hline $\begin{array}{l}\text { The Eleventh } \\
\text { hypothesis }\end{array}$ & $\begin{array}{l}\text { H11: Sale promotion influences the perceived value of } \\
\text { Khalkhal as a tourism destination }\end{array}$ & 0.125 & 0.750 & Approved \\
\hline $\begin{array}{l}\text { The twelfth } \\
\text { hypothesis }\end{array}$ & $\begin{array}{l}\text { H12: Physical evidence influences the perceived value } \\
\text { of Khalkhal as a tourism destination }\end{array}$ & 0.466 & 0.000 & Approved \\
\hline $\begin{array}{l}\text { The thirteenth } \\
\text { hypothesis }\end{array}$ & $\begin{array}{l}\text { H13: Perceived quality influences the loyalty of } \\
\text { Khalkhal as a tourism destination }\end{array}$ & 0.422 & 0.000 & Approved \\
\hline $\begin{array}{l}\text { The fourteenth } \\
\text { hypothesis }\end{array}$ & $\begin{array}{l}\text { H14: Destination image influences the loyalty of } \\
\text { Khalkhal as a tourism destination }\end{array}$ & 0.509 & 0.000 & Approved \\
\hline $\begin{array}{l}\text { The fifteenth } \\
\text { hypothesis }\end{array}$ & $\begin{array}{l}\text { H15: Perceived value influences the loyalty of } \\
\text { Khalkhal as a tourism destination }\end{array}$ & 0.566 & 0.000 & Approved \\
\hline $\begin{array}{l}\text { The sixteenth } \\
\text { hypothesis }\end{array}$ & $\begin{array}{l}\text { H16: price influences the loyalty of Khalkhal as a } \\
\text { tourism destination }\end{array}$ & 0.240 & 0.016 & Approved \\
\hline $\begin{array}{l}\text { The seventeenth } \\
\text { hypothesis }\end{array}$ & $\begin{array}{l}\text { H17: Physical evidence influences the loyalty of } \\
\text { Khalkhal as a tourism destination }\end{array}$ & 0.070 & 0.000 & Approved \\
\hline $\begin{array}{l}\text { The eighteenth } \\
\text { hypothesis }\end{array}$ & $\begin{array}{l}\text { H18: Distribution influences the loyalty of Khalkhal } \\
\text { as a tourism destination }\end{array}$ & 0.311 & 0.000 & Approved \\
\hline $\begin{array}{l}\text { The nineteenth } \\
\text { hypothesis }\end{array}$ & $\begin{array}{l}\text { H19: People influences the loyalty of Khalkhal as a } \\
\text { tourism destination }\end{array}$ & -0.109 & 0.278 & Rejected \\
\hline $\begin{array}{l}\text { The twentieth } \\
\text { hypothesis }\end{array}$ & $\begin{array}{l}\text { H20: Sale promotion influences the loyalty of } \\
\text { Khalkhal as a tourism destination }\end{array}$ & 0.310 & 0.002 & Rejected \\
\hline
\end{tabular}

In order to examine the difference between the different groups through the comparison of the means, we can compare the significance and examine the significance of the differences between classes or groups. As a secondary purpose of the study, we want to examine the difference between tourist groups in terms of their assessment of loyalty to tourism destinations in four demographic dimensions: gender, marital status, age, and education. The average of Mann-Whitney and Kruskal-Wallis tests was used for this purpose. To compare the mean age and education of tourists, we use the Kruskal-Wallis test. Since there are four groups, the test results are as follows: 
Table 4. Results of the mean for different groups in relation to perceived value, perceived quality and loyalty

Research Hypothesis

There is a significant relationship between the perception of women and men about loyalty to Khalkhal tourism destination.

There is a significant relationship between the perception of married and single participants about loyalty to Khalkhal tourism destination.

There is a significant relationship between the perceptions various age groups of tourists about loyalty to the destination of Khalkhal tourism.

There is a significant relationship between the perceptions of tourists' groups about loyalty to Khalkhal tourism destinations.

In this study, it was observed that marketing mix elements can affect loyalty to the destination of tourism in different ways and the degree of influence of each element also varies. Table below shows the degree of influence of each of these elements using the path analysis technique on loyalty to Khalkhal tourism destination. Physical evidence of destination has the highest impact on loyalty to the Khalkhal tourism destination, which varies by one unit of change in the standard deviation of the physical evidence of the destination, along with the standard deviation of loyalty to the Khalkhal tourist destination as 0.189 .

The elements of promotion, people and price are ranked respectively and the distribution element seems to have no effect on the lack of activities related to the distribution of tourist attractions in the loyalty to the Khalkhal tourist destination.

Table 5. Ranking of marketing mix elements based on the degree of effectiveness

\begin{tabular}{clc}
\hline Rank & $\begin{array}{l}\text { Independent } \\
\text { variable }\end{array}$ & Effect \\
1 & $\begin{array}{c}\text { Physical } \\
\text { evidence }\end{array}$ & 0.189 \\
& Promotion & 0.175 \\
2 & people & -0.047 \\
3 & Price & 0.00626 \\
4 & Distribution & 0 \\
5 & & \\
\hline
\end{tabular}

\section{Discussion}

In this study, the relationship between some elements of marketing mix and loyalty, perceived quality and destination image of tourists was investigated. The discussed elements of marketing mix included price, distribution, sale promotion, people and product. Regarding the distribution variable, its effect on perceived quality of the Khalkhal tourist destination image was approved. These findings are in line with the study of Geon et al (2011) and against the results of the study by Huang and Sarigöllü (2012) since they found no relationship between distribution and perceived quality and also its effect on perceived value of destination is rejected.

In terms of sales promotion, its influence on destination image, perceived quality, and perceived value was confirmed which is in line with the studies of Soleimani and Mansuri Moaied (2012), Tang and Hawley (2009) and Beristain and Zorrilla (2011). Soleimani and Mansouri Moaied (2012) stated that various promotion tools had a positive effect on destination image of tourists. The relationship with the price variable, its impact on the quality and verifiability of loyalty and on the destination image has been rejected, which is consistent with the results of the research by Iranzadeh et al. (2012) and Beristain and Zorrilla (2011) in which the price has positive effect on loyalty, but the price effect Contrary to the results of the present research on perceived quality has been rejected which is against the research findings.It is also contrary to the results of Sehat et al. (2012) who rejected the effect of price on quality.

The effect of physical evidence variable on all three variables of perceived quality, perceived value, and loyalty was approved. The effect of people variable on perceived quality, perceived value, and loyalty have also been rejected, which is in line with the results of Tang and Hawley's (2009) which has confirmed their impact on 
quality and loyalty. Also, the effect of perceived quality on loyalty to the destination has been rejected and the effect of perceived value on loyalty has also been rejected, which is in line with the results of the research, Nahri Dehghani et al. (2014) which stated that the perceived value of a tourist destination cannot affect loyalty to that destination, and contrary to the results of the research, Hemati and Zahrani (1393) and Faith and Ayubi (2010). However, the effect of the destination image on the loyalty was confirmed, according to the results of the research Hemmati and Zahrani (1393), Imani Khoshko and Ayoubizade (2010, a) and Anari Dehghani et al. (1393), and in their research, the image of the destination has a positive relationship with loyalty to the destination of tourism.

\section{Conclusion}

According to the results of statistical analysis, sales promotion, people and physical evidence had the highest impact on perceived quality, perceived value and loyalty of customers, and ultimately on the image of the Khalkhal tourist destination. As for the people, it should be said that because most of the staff at hotels, restaurants, and other centers who directly deal with tourists have not learned much about how to communicate with the tourists, they think of immediate economic returns in communication with tourists.

Also, in field studies, some tourists expressed their dissatisfaction with the inappropriate behavior of some owners of residential centers. In this regard, despite holding training courses by organization for activists of various sectors of tourism, the Center for Advice, Education and Research of Ardabil Development Center, in cooperation with the Directorate General of Heritage, Handicrafts and Tourism of Ardabil province, unfortunately, most tourism activists are not obliged to attend these courses and so they do not attend this courses, so the absence of these activists in situations results in inappropriate treat with tourists. As a result, the managers of Khalkhal tourism destination are advised to continuously monitor the training of activists in all areas related to tourism, the owners and managers of residential centers need to be trained in tourist training courses as well as native communities on how to communicate with and treat tourists and get acquainted with the tourist attractions of the city.

The second most influential factor was the sale promotion and advertising which affected both the destination image, perceived quality and perceived value of tourism destination. In this regard, only two of the resident centers do this and, of course, do the promotion themselves. On the other hand, there is no cluster cooperation between tourism activists, and each of them creates advertisements or advertises on local city websites, which is very limited. However, during an interview with the director of cultural heritage, handicrafts and tourism in Khalkhal city, he said that given the cooperation of this office with hotels, restaurants etc., it has been stipulated that a wide cooperation should be established between the influential clusters in Khalkhal city tourism.

Also, according to interviews with tourists, most tourists mentioned their presence in the city as a result of being familiar with their friends, which indicates the weakness in marketing and advertising of city tourism. Therefore, Khalkhal tourism destination managers are advised to use a wider range of promotional programs such as discounted prices, such as gifts and services for tourism destinations. To increase the perceived value of tourists, it is highly important to pay enough attention to propaganda and other promotional instruments such as public relations and news interviews and tourism destination managers must try to enforce them more effectively.

From among the combined factors of marketing, physical evidence is also a factor influencing all three variables of perceived quality, perceived value, and loyalty to tourism destination. In this context, it should also be noted that some tourists complained about the inadequate situation of the city. In this regard, it should be noted that, unfortunately, the entrance of the city is a place for the evacuation of construction waste. In the majority of cases, the entrance of the city is full of car repair shops and mechanics, which do not give a good look to the city, and also a good image of the city from the three main routes of the entrance of the tourists to the city (Asalem-Khalkhal, Ardebil-Khalkhal and Hashjin-Khalkhal roads) in mind of tourists. However, tourists were very pleased with the natural landscape of the city, which translates into the natural and pristine condition of the city. But in some cases, undesirable actions have destroyed some of the people and even investors of these landscapes. An example of these on the Khalkhal road to Clor, which is the road to the future (with the addition of the Khalkhal-Klor-Darm road), will become one of the main sources of entry for tourists. The existence of sand mines produces a lot of contamination and a natural landscape. Becker has destroyed this area, especially since these mines were located on the route of the Imamzadeh Abdullah Koolur as a tourism sample area, and a hotel has been constructed near the sand mines where continuation of these mines' activities will cause great damage to the city's tourism.

Therefore, it is recommended to provide a comprehensive plan on how to deploy applications, especially in the city's entry points, in cooperation with the cultural heritage, handicrafts and tourism, and municipalities. 
Avoiding dumping spills and waste at the city's entry points in cooperation with municipalities, seafarers, water companies and other relevant organizations. Also, monitoring the activities of leased houses in the city area is carried out by the Police Department and the Heritage, Handicrafts and Tourism Department of Khalkhal. On the other hand, the destruction of natural and pristine landscapes and the non-issuance of permits for activities to mine in pristine areas of tourism should be done in cooperation with the Office of Natural Resources and Watersheds, Police and Judiciary.

The next element is the price that has a positive impact on quality and loyalty and negatively influences the destination image. When people flock to the city during the peak tourism time, some people and businessmen offer tourists with expensive prices due to lack of knowledge and training for making use of the existing conditions. Even some people, in the spring and summer, turn their homes into tourist resorts and suites but there is no control over them while the researches indicate the low quality of these centers. Despite the fact that most of these centers do not provide proper services to tourists, they instead receive large amounts of money from tourists, which is especially common during the peak season of tourism. Therefore, it is suggested that the relevant departments prevent such centers from continuing their activities and obtaining permits. It is essential for the organization of cultural heritage, crafts and tourism to introduce them for obtaining permits and licenses. If licensed, the Cultural Heritage, Craft and Tourism Organization will be able to control the prices and services provided by these centers.

According to the results of the study, perceived quality influences loyalty. Therefore, the present results indicate that improving perceived quality is the best way to create future visits, even if the tourist is dissatisfied or has a poor experience of traveling to a location. As a result, efforts to create and improve the perceived quality of the destination may facilitate visiting behaviors and, accordingly, contribute to the success of the destination and the development of tourism. Thus, the managers of tourism and recreation destination must work on the inherent and essential elements of the destination, such as advertising, promotion, new attraction as an instrument to improve the perceived quality of the destination.

\section{References}

Aghayyashshin, M. (2009). Tourism Development Planning through the Capability and Tourism Attractions in Khalkhal (Unpublished Master's Thesis). Islamic Azad University, Rasht, Iran. (In Persian)

Alizadeh, M. (2012). Strategic Planning for Tourism Development with Emphasis on Khalkhal (Unpublished Master's Thesis). University of Tehran, Tahran, Iran. (in Persian)

Anaridhaghani, F., Razavi Yuldtabadi, H., \& Ghaffari, M. (2014). Analysis of Factors Affecting the Loyalty of Tourists to Tourism (Case Study: Foreign Tourists Traveling to Isfahan City). Journal of Management of Organizational Culture, 3, 865-882. (in Persian)

Baker, D. A., \& Crompton, J. L. (2000). Quality, satisfaction, and behavior intentions. Annals of Tourism Research, 27(3), 785-804. https://doi.org/10.1016/S0160-7383(99)00108-5

Beerli, A., \& Marting, J. D. (2004). Factors Influencing Destination Image. Annals of Tourism Research, 31(3), 657-681. https://doi.org/10.1016/j.annals.2004.01.010

Beristain, J., \& Zorrilla, P. (2011). The relationship between store image and store brand equity: A conceptual framework and evidence from hypermarkets. Journal of Retailing and Consumer Services, 18, 562-574. https://doi.org/10.1016/j.jretconser.2011.08.005

Brady, M. K., \& Cronin, J. (2001). Some new thoughts on conceptualizing perceived service quality: a hierarchical approach. Journal of Marketing, 65(3), 34-49. https://doi.org/10.1509/jmkg.65.3.34.18334

Chao, W. Z. (2005). Marketing tools as factors in destination image formation (Unpublished Master's Thesis). San Jose State University, California, United States.

Charlotte, M. E., \& Ritchie, J. R. B. (2003). The Meaning and Measurement of Destination Image. The Journal of Tourism Studies, 14(1), 37-48.

Chen, C. F., \& Chen, F. S. (2010). Experience Quality, Perceived Value, Satisfaction and Behavioral Intentions for Heritage Tourists. Tourism Management, 31(1), 29-35. https://doi.org/10.1016/j.tourman.2009.02.008

Chen, J. S., \& Gursoy, D. (2001). An investigation of tourists' destination loyalty and preferences. International $\begin{array}{llll}\text { Journal of Contemporary Hospitality } & \text { Management, } & \text { 13(2), }\end{array}$ https://doi.org/10.1108/09596110110381870

Darnell, A. C., \& Johnson, P. S. (2001). Repeat visits to attractions: A preliminary economic analysis. Tourism 
Management, 22, 119-126. https://doi.org/10.1016/S0261-5177(00)00036-4

Echtner, C. M., \& Ritchie, R. C. (1993). The meaning and measurement of destination image. Journal of Tourism Studies, 31(4), 3-13. https://doi.org/10.1177/004728759303100402

Ghadiri, M., Mojbatei, Souri, F., Shafiei Arabi, M., \& Bahrami, M. (2013), Evaluation and Prioritization of Indicators Effective in Marketing of Rural Tourism with Marketing Mix Model 7p; Case Study: Selected Cities of Mazandaran Province. Quarterly Journal of Urban and Rural Management, 32, 139-152 (in Persian)

Gholizadeh, S. N. (2012). Destination Brand Equity, Satisfaction and Revisit Intention: An Application in TRNC as a Tourism Destination (Unpublished Master's Thesis). Eastern Mediterranean University, Famagusta, Northern Cyprus.

Gitelson, R. J., \& Crompton, J. L. (1984). Insights into the repeat vacation phenomenon. Annals of Tourism Research, 11, 199-217. https://doi.org/10.1016/0160-7383(84)90070-7

Hassannejad, M., Barati, J., Rafiei, H., \& Mazhari, M. (2014). Identification of Development Strategies for Religious Tourism Investment in Iran (Case Study: Imam Reza Shrine). Journal of Tourism Planning and Development, 3(9), 109-88. (In Persian)

Hemati, R., \& Zahrani, D. (2014). Investigating factors affecting the satisfaction and loyalty of foreign tourists to Isfahan as a tourism brand. Journal of Tourism Planning and Development, 3(10), 182-204 (in Persian)

Huang, R., \& Sarigöllü, E. (2012). How brand awareness relates to market outcome, brand equity, and the marketing mix. Journal of Business Research, 65, 92-99. https://doi.org/10.1016/j.jbusres.2011.02.003

Huh, J. (2006). Destination Branding as an Informational Signal and Its Influence on Satisfaction and Loyalty in the Leisure Tourism Market (Unpublished doctoral dissertation). Virginia Tech, United States.

Ilkhani, L., Vali Shariat Panahi, M., Aghazadeh, M., \& Moghadamnia, E. (2016). The Impact of Tourism Management on Social and Cultural Developments in Qom City. Urban and Rural Management Quarterly, 45, 321-338. (in Persian)

Imani Khoshko, M., \& Ayoubizade, H. (2010, a). Comparative study of Brand Value of Kish and Qeshm Tourist Destinations from the Point of View of the Internal Tourists' Perceptions. Proceedings of the Sixth National Cultural-Tourism Conference of the Persian Gulf. (in Persian)

Imani Khoshko, M., \& Ayoubizade, H. (2010, b). Factors Affecting Brand Equity in Tourism Destination of Yazd. Journal of Tourism Studies, 13, 113-137. (in Persian)

Iranzadeh, S., Ranjbar, A., \& Poursadegh, N. (2012). Investigating the effect of marketing mix on brand equity. Journal of Research in Marketing Research, 2(3), (6). (in Persian)

Jung Sun, K. H. (2013). Experience, Attraction, and Perceived Value of the Seniors Community Chorus Concert. International Review of Management and Business Research, 2(1), 234-249.

Kazemi, M. (2008). Analysis of the Effect of Zahedani Citizens Perception on the Development of Chabahar Tourism. Geography and Development Quarterly, 12, 81-100. (in Persian)

Kazemi, M. (2011). Tourism Management (1st ed). Tehran, TH: SAMT Publishing. (in Persian)

Kim, J., \& Hyum, Y. (2010). A model to investigate the influence of marketing-mix efforts and corporate image on brand equity in the IT software sector. Industrial Marketing Management, 40(3), 424-438. https://doi.org/10.1016/j.indmarman.2010.06.024

Konecnik, M., \& De Chernatony, L. (2010). A Systematic Approach to Branding Slovenia. Proceedings of the Thought Leaders in Brand Management 6th International Conference, April.

Kozak, M. (2001). Repeaters' behavior at two distinct destinations. Annals of Tourism Research, 28(3), 784-807. https://doi.org/10.1016/S0160-7383(00)00078-5

Kozak, M., \& Rimmington, M. (2000). Tourist satisfaction with Mallorca, Spain, as an off-season holiday destination. Journal of Travel Research, 38(3), 260-269. https://doi.org/10.1177/004728750003800308

Lin, H. H. (2011). A Multidimensional Customer-based Brand Equity and its Application to Religious Events: The Case of Mazu (Unpublished doctoral dissertation). Texas Technology University, Lubbock, United States.

Milman, A., \& Pizam, A. (1995). The role of awareness and familiarity with a destination: The central Florida 
case. Journal of Travel Research, 33(3), 21-27. https://doi.org/10.1177/004728759503300304

Nam, J., Ekinci, Y., \& Whyatt, G. (2011). Brand Equity, Brand Loyalty and Consumer Satisfaction. Annals of Tourism Research, 38(3), 1009-1030. https://doi.org/10.1016/j.annals.2011.01.015

Pamela, L, A., \& Robert, B, S. (1999). Strategies for building consumer brand preference. Journal product \& brand management, 8(2), 130-144. https://doi.org/10.1108/10610429910266986

Petrick, J. F., Morais, D. D., \& Norman, W. C. (2001). An examination of the determinants of entertainment vacationers' intentions to revisit. Journal of Travel Research, 40(1), 41-48. https://doi.org/10.1177/004728750104000106

Reichheld, F. F., \& Sasser, W. E. (1990). Zero, defection: Quality comes to service. Harvard Business Review, 68(1), 105-111.

Ross, G. F. (1993). Ideal and actual images of backpacker visitors to northern Australia. Journal of Travel Research, 32(2), 54-57.

Sahat, S., Bammalavi Rostami, H., \& Kashkoli, M. (2012). the Effect of Marketing Mix on the Special Value of the Commercial Name of the Entrepreneur Insurance Company. Journal of Commercial Business Management School, 4(12), 90-71 (in Persian)

Soleimani, S., \& Mansouri Moaied, F. (2012). Marketing Tools and Thinking Image of Tourists from Destination. Journal of Tourism Management Studies, 7(18), 91-111. (in Persian)

Tong, X., \& Hawley, J. (2009). Creating brand equity in the Chinese clothing markets the effect of selected marketing activities on brand equity dimensions. Journal of Fashion Marketing and Management, 13(4), 566-581. https://doi.org/10.1108/13612020910991411

Yoo, B., Donthu, N., \& Lee, S. J. (2000). An examination of selected marketing mix elements and brand equity. Journal of the Academy of Marketing Science, 28(2), 195-211. https://doi.org/10.1177/0092070300

Yoon, Y. S, Lee, J. S., \& Lee, C. K. (2010). Measuring Festival Quality and Value Affecting Visitors' Satisfaction and Loyalty Using a Structural Approach. International Journal of Hospitality Management, 29(2), 335-342. https://doi.org/10.1016/j.ijhm.2009.10.002

Yuksel, A. (2001). Managing customer satisfaction and retention: A case of tourist destinations, Turkey. Journal of Vacation Marketing, 7(2), 153-168. https://doi.org/10.1177/135676670100700205

Zanganeh, Y., \& Shamsollahzadeh, Y. (2012). Investigating and analyzing the role of image destination in the development of tourism industry (Case study: Tabriz Metropolis). Journal of Geography and Planning, 16(41), 153-168. (In Persian)

Zeithaml, V. A. (1998). Consumer perceptions of price, quality, and value: a means-end model and synthesis of evidence. Journal of Marketing, 52(3), 2-22. https://doi.org/10.2307/1251446

\section{Copyrights}

Copyright for this article is retained by the author(s), with first publication rights granted to the journal.

This is an open-access article distributed under the terms and conditions of the Creative Commons Attribution license (http://creativecommons.org/licenses/by/4.0/). 